\title{
KIỂU GEN VÀ KIỂU HÌNH CỦA TĂNG TRIGLYCERIDE MÁU TIÊN PHÁT Ở TRẺ EM
}

\section{TÓM TẮT}

Tăng triglyceride máu tiên phát là bệnh lý di truyền hiếm gặp, chủ yếu do bất thường liên quan đến quá trình chuyển hoá chylomicron dẫn đến tăng triglyceride. Các gen đã được xác định khi có đột biến gây tăng triglyceride là LPL, APOC2, APOA5, LMF1, GPIHBP1 và APOE. Mục tiếu: mô tả đặc điểm lâm sàng, hóa sinh, biến chứng và kiểu gen của các bệnh nhi tăng triglyceride máu tiên phát. Đối tượng: 6 bệnh nhi tăng triglyceride có đột biến các gen liên quan. Phương pháp nghiên cứu: nghiên cứu một loạt ca bệnh. Kết quả: tuổi chẩn đoán sớm nhất là 1,4 tháng và muộn nhất là 12 tuổi; có 5 bệnh nhân nữ và 1 bênh nhân nam; 1 bệnh nhân có u hat vàng, 3 bệnh nhân có biến chứng viêm tuỵ cấp, 3 bệnh nhân có lách to, 1 bênh nhân có gan to, 2 bênh nhân có đau bụng tái diễn. Nồng độ triglyceride huyết thanh trung bình khi được chẩn đoán là $16,86 \pm 3,77 \mathrm{mmol} / \mathrm{l}$, nồng độ cholesterol toàn phân trung bình trong huyết thanh là $3,77 \pm 0,74 \mathrm{mmol} / \mathrm{l} ; 4$ bệnh nhân có đôtt biến trên gen GPIHBP1; 1 bệnh nhân có đột biến trển gen LPL và 1 bệnh nhấn có đột biến trên gen APOE. Cả 6 bệnh nhân đều đáp ứng với chế độ ăn giảm mõ̃ máu. Kết luận: tăng triglyceride máu tiên phát có biến chứng nguy hiểm viêm tụy cấp, bệnh cần được chẩn đoán sớm để điều trị dự phòng. Phân tích đột biến gen giúp chẩn đoán sớm và tư vấn di truyền phòng bệnh.

Tư khoá: tăng triglyceride máu tiên phát, các gen GPIHBP1, LPL và APOE

\section{SUMMARY}

\section{GENOTYPE AND PHENOTYPE OF PRIMARY HYPERTRIGLYCERIDEMIA IN CHILDREN}

Primary hypertriglyceridemia is a rare, autosomal recessive disorder characterized by the accumulation of large triglyceride-rich lipopoteins in the circulation (chylomicronemia), which leads to increase serum triglyceride. The genes have been identified as causes of hypertrilyceridemia are LPL, APOC2, APOA5, LMF1, GPIHBP1, and APOE qenes. Objectives: to describle clinical characteristics and genotype of children with primary hypertriglyceridemia who were identified mutations in related qenes. Subjects and method: a case series study including clinical and biochemistry data of 6 patients. Mutation analysis using next qeneration sequencing (familial dyslipidemia panel including 31 genes). Results: The aqe at presentation was from 1.4 months old to 12 years old. There were 5 girls and 1 boy. Xanthomas was only seen in 1

*Bênh viện Nhi Trung Uơng

Chịu trách nhiệm chính: Vũ Chí Dũng

Email: dungvu@nch.org.vn

Ngày nhận bài: 5.01 .2021

Ngày phản biên khoa hoc: 25.2.2021

Ngày duyệt bài: 10.3.2021

\section{Đỗ Thị Thanh Mai*, Vũ Chí Dũng*}

patient. Acute pancreatitis was reported in 3 patients. Splenomeqaly was recoqnized in 3 patients. Hepatomeqaly was reported in 1 patient. Recurrent abdominal pain was presented in 2 cases. The averaqe serum trialyceride level was $16.86 \pm 3.77$ $\mathrm{mmol} / \mathrm{l}$, average of serum total cholesterol level was $3.77 \pm 0.74 \mathrm{mmo} / \mathrm{l}$. Mutations in GPIHBP1 gene was identified in 4 cases, mutation in LPL gene was identified in 1 case, mutation in APoE was revealed in 1 patient. All patients responded to low fat diet. Conclusions: Primary hypertriglyceridemia has a dangerous complication of acute pancreatitis. The disease should be diagnosed early for preventive treatment. Genome sequencing analysis need to perform for early treatment and genetic counseling.

Keywords: primary hypertriglyceridemia, GPIHBP1, LPL and APOE gene

\section{I. ĐẶT VẤN ĐỀ}

Tăng triglyceride máu tiên phát là nhóm bệnh hiếm gặp, thường là di truyền lặn nhiễm sắc thể thường, đặc trưng bởi tăng lipoprotein giàu triglyceride trong hệ thống tuần hoàn. Bệnh có thể biểu hiện với các triệu chứng lâm sàng như u hạt vàng, chậm phát triển thể chất và viêm tuy. tái phát. Các gen liên quan thường gặp nhất là đột biến gen LPL mã hoá lipoprotein lipase (LPL), enzym này xúc tác cho quá trình thuỷ phân triglyceride ở các mô không phải là gan. Tỷ lệ gặp đồng hợp tử đột biến gen LPL là 1/1000000 và chiếm $95 \%$ trong số các nguyên nhân gây tăng triglyceride do di truyên đơn gen [1]. Các gen khác khi đột biến gây tăng triglyceride là ApoC2, gen này mã hoá cho yếu tố đồng vận của LPL; gen GPIHBP1 mã hoá cho protein liển kết với LPL ở trong khoảng kẽ và vận chuyển chúng vào bề mặt bên trong của các tế bào nội mô [2]; đột biến gen LMF1, mã hoá cho protein cân thiết sau phiên mã của LPL [3]; đột biến gen ApoA5, mã hoá cho chất có vai trò ổn định LPL; hay đột biến gen $A p o E$, mã hoá cho protein cấu trúc của chylomycron, VLDL, HDL, đóng vai trò phối tử thụ thể của các enzym [4]. Tăng triglycerid ở trẻ em dễ bi bỏ qua, chẩn đoán muộn và có thể gây nên các biến chứng cấp nguy hiểm như viêm tụy và hậu quả tim mạch. Hơn nữa, bệnh có tính chất di truyền nên nhiều thành viên trong gia đình có thể mắc bệnh hoặc mang gen bệnh, việc phát hiện đột biến các gen có liên quan sẽ giứp chẩn đoán xác định, sàng lọc phát hiện sớm các bệnh nhân chưa có biểu hiện lâm sàng và tư vấn di truyền phòng bệnh. 
Xuất phát từ lý do trên, nghiên cứu được tiến hành với mục tiêu: Mô tả kiểu hình lâm sàng, hóa sinh, biến chứng và kiểu gen của các bệnh nhi tăng triglycerid.

\section{II. ĐỐI TƯỢNG VÀ PHƯƠNG PHÁP NGHIÊN CỨU}

Đối tượng nghiên cứu bao gồm 6 bệnh nhân từ 6 gia đình riêng rẽ được chẩn đoán và điều trị tăng triglyceride tại khoa Nội tiết - Chuyển hóa Di truyền, bệnh viện Nhi Trung Ương từ 1/2019 - 12/2020. Các bệnh nhân này đều phát hiện

\section{KẾT QUẢ NGHIÊN CỨU}

\section{1 Đăc điểm lâm sàng và biến chứng}

Bảng 3.1. Đặc điểm lâm sàng của các bệnh nhân nghiên cứu

\begin{tabular}{|c|c|c|c|c|c|c|c|c|c|}
\hline $\begin{array}{c}\text { Ca } \\
\text { bệnh }\end{array}$ & $\begin{array}{c}\text { Tuối chấn } \\
\text { đoán }\end{array}$ & Giới & $\begin{array}{c}\text { Triệu chứng } \\
\text { đển khám }\end{array}$ & BMI & Huyết áp & $\begin{array}{c}\text { U hạt } \\
\text { vàng }\end{array}$ & Gan to & Lách to & $\begin{array}{c}\text { Viêm } \\
\text { tuy cấp }\end{array}$ \\
\hline 1 & 9,8 tháng & Nữ & $\begin{array}{c}\text { Xuất huyết } \\
\text { dưới da }\end{array}$ & 15 & - & Có & Không & Không & Không \\
\hline 2 & 6,5 tháng & Nữ & Nôn & 15,4 & - & Không & Không & Không & Có \\
\hline 3 & 12 tuối & Nam & Đau bụng & 17,2 & $100 / 60$ & Không & Có & Có & Có \\
\hline 4 & 7 tháng & Nữ & Nôn & 13,9 & $88 / 55$ & Không & Không & Không & Có \\
\hline 5 & 1,4 tháng & Nữ & Chướng bụng & 18,6 & - & Không & Không & Có & Không \\
\hline 6 & 10,7 tuô̂i & Nữ & Đau bụng & 14,2 & $90 / 55$ & Không & Không & Có & Không \\
\hline
\end{tabular}

Ghi chú: (-) không có dữ liệu
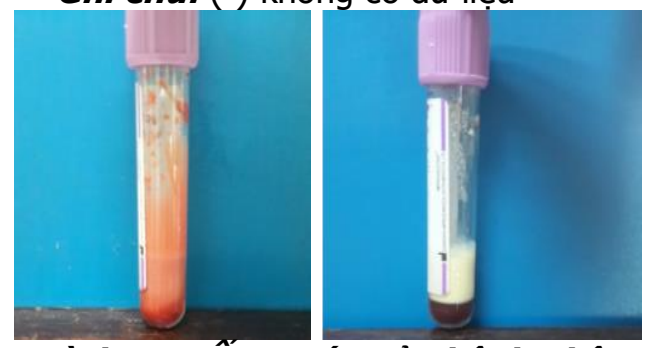

Hình 3.1. Ông máu của bệnh nhân tăng Triglyceride được các đột biến của các gen có liên quan.

Nghiên cứu một loạt ca bệnh bao gồm mô tả đặc điểm lâm sàng, hóa sinh, biến chứng và kiểu gen. Phân tích đột biến các gen gây tăng lipid máu tiên phát: DNA được chiết tách từ bạch cầu máu ngoại vi, sử dụng phương pháp giải trình tự gen thế hệ mới để xác định đột biến gây bệnh. Nhóm gen gây tăng lipid máu tiên phát được khảo sát bao gồm 31 gene được phân tích và đối chiếu với dữ liệu từ ngân hàng gen.

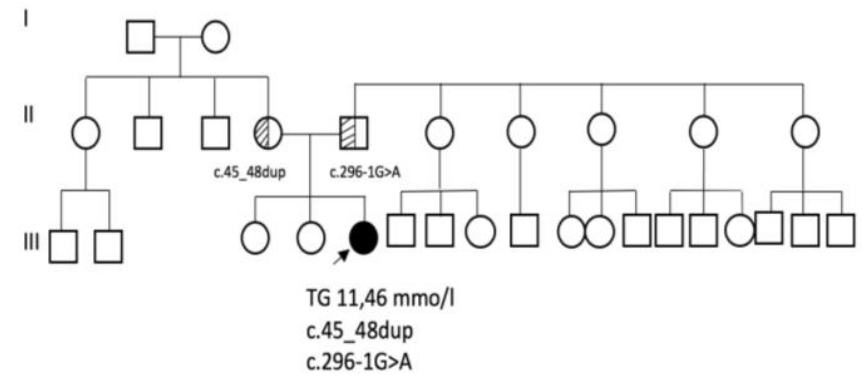

Hình 3.2. Phả hệ ca bệnh 2

Bảng 3.2. Đặc điểm biến chứng viêm tuy câp ở 3 ca bệh

\begin{tabular}{|c|c|c|c|c|}
\hline $\begin{array}{c}\text { Ca } \\
\text { bệnh }\end{array}$ & $\begin{array}{c}\text { Tuối khởi phát } \\
\text { biến chứng }\end{array}$ & Số lân & $\begin{array}{c}\text { Nồng độ triglyceride } \\
\text { (mmol/I) }\end{array}$ & $\begin{array}{c}\text { Nông đố Lipase/P- } \\
\text { amylase (U/I) }\end{array}$ \\
\hline 2 & 7 tuổi & 3 & $\begin{array}{c}\text { Lần 1- } \\
\text { Lần 2: } 8,29 \\
\text { Lần 3*: 12,79 }\end{array}$ & $\begin{array}{c}\text { Lần } 2: 415,4 / 261,31 \\
\text { Lần 3: } 646 / 308,6\end{array}$ \\
\hline 3 & 6,5 tháng & 1 & $* * 17,28$ & $143,44 / 17,24$ \\
\hline 4 & 6 tháng & 2 & $\begin{array}{c}\text { Lần 1- } \\
\text { Lần 2- }\end{array}$ & $\begin{array}{c}\text { Lần 1- } \\
\text { Lần 2- }\end{array}$ \\
\hline
\end{tabular}

Ghi chú: (-) không có dữ liệu báo cáo; * Không có dữ liệu triglyceride trước điều trị viêm tuy, xét nghiệm thực hiện sau điều trị 3 ngày; **Naày đâuu huyết tương đục không định lượng được triglyceride, xét nghiệm thực hiện sau 3 ngày điêu trị viêm tuy cấp.

3.2 Đặc điểm hóa sinh và các đột biến của các gen liên quan

Bảng 3.3. Đăc điểm sinh hoá của các bệnh nhân nghiên cứu

\begin{tabular}{|c|c|c|c|c|}
\hline Ca bệnh & $\begin{array}{c}\text { Nồng độ } \\
\text { triglyceride } \\
\text { (mmol/l) }\end{array}$ & $\begin{array}{c}\text { Nồng độ } \\
\text { cholesterol toàn } \\
\text { phân (mmol/I) }\end{array}$ & $\begin{array}{c}\text { Nồng độ LDL- } \\
\text { cholesterol } \\
\text { (mmo/l) }\end{array}$ & $\begin{array}{c}\text { Nồng độ HDL- } \\
\text { cholesterol } \\
\text { (mmol/I) }\end{array}$ \\
\hline 1 & 11,46 & 3,89 & 1,82 & 0,32 \\
\hline 2 & 21,84 & 4,46 & 1,03 & 0,73 \\
\hline
\end{tabular}




\begin{tabular}{|c|c|c|c|c|}
\hline 3 & 14,41 & 5,31 & - & 0,35 \\
\hline 4 & 16,73 & 5,47 & 2,16 & 0,39 \\
\hline 5 & 20,2 & 3,7 & 1,6 & 0,1 \\
\hline 6 & 16,53 & 4,96 & - & - \\
\hline Trung binh & $16,86 \pm 3,77$ & $4,63 \pm 0,73$ & $1,65 \pm 0,47$ & $0,37 \pm 0,22$ \\
\hline
\end{tabular}

Ghi chú: (-) không có số liệu

Bảng 3.4. Các đột biến của các gen có liên quan ở các bệnh nhân nghiên cứu

\begin{tabular}{|c|c|c|c|c|}
\hline Ca bệnh & & Kiếu gen (cDNA) & Kiếu gen (protein đột biến) & Di truyền \\
\hline 1 & GPIHBP1 & c.45_48dup/c.296-1G>A & p.P17AfsX22)/p.(?) & lặn \\
\hline 2 & GPIHBP1 & c.45_48dup/c.45_48dup & p.P17AfsX22)/p.P17AfsX22 & lặn \\
\hline 3 & GPIHBP1 & c.45_48dup/c.45_48dup & p.P17AfsX22)/p.P17AfsX22 & lặn \\
\hline 4 & GPIHBP1 & c.45448dup/c.45_48dup & p.P17AfsX22)/ p.P17AfsX22 & lặn \\
\hline 5 & LPL & c.355del/ c.898G>C & p.E119SfsX53/p.G300R & lặn \\
\hline 6 & ApoE & c.388T>C & p.C130R & trội \\
\hline
\end{tabular}

3.3 Kết quả điêu trị: Bệnh nhân được điều trị bằng chế độ ăn giảm mõ̃, dùng dầu MCT để chế biến món ằn cho trẻ lớn, sữa công thức có chứa MCT cho trẻ nhỏ; dùng Omega 3 liều 1,2g/ ngày; không có bệnh nhân dùng thuốc hạ mõ máu. Kết quả điều trị được trình bày tạ bảng 3.5.

\section{Bảng 3.5. Kêt quả điều trị}

\begin{tabular}{|c|c|c|c|}
\hline $\begin{array}{c}\text { Ca } \\
\text { bệnh }\end{array}$ & $\begin{array}{c}\text { Nồng độ } \\
\text { triglyceride } \\
\text { (mmol/I) }\end{array}$ & $\begin{array}{c}\text { Nồng độ } \\
\text { cholesterol } \\
\text { toàn phân } \\
\text { (mmol/I) }\end{array}$ & $\begin{array}{c}\text { Thời gian } \\
\text { điêuu } \\
\text { trị*** } \\
\text { (tháng) }\end{array}$ \\
\hline 1 & 3,08 & 4,01 & 4 \\
\hline 2 & 3,56 & 2,78 & 1,3 \\
\hline 3 & 7,03 & 2,52 & 8 \\
\hline 4 & 8,65 & 4,67 & 9,6 \\
\hline 5 & 6,8 & 2,6 & 15 \\
\hline 6 & 4,13 & 3,27 & 1 \\
\hline
\end{tabular}

Ghi chú: *** thời gian bệnh nhân đạt được nồng độ Triglyceride thấp nhất.

\section{BÀN LUÂ̂N}

Tất cả các bệnh nhân nghiên cứu đều có BMI $<85$ bách phân vị so với tuổi và giới. Như vậy, các trẻ này đều không có quá cân và béo phì và dữ liệu này giúp bước đầu có thể loại trừ được một trong các nguyên nhân thứ phát gây tăng triglycerid máu. Các triệu chứng lâm sàng nghèo nàn, trong 6 ca bệnh chỉ có duy nhất 1 bênnh nhân có u hạt vàng, các bệnh nhân khác không có triệu chứng đặc trưng, thậm chí ca bệnh số 3 chỉ được chẩn đoán sau ba lần có biến chứng viêm tuyy cấp. 3 bệnh nhân có biến chứng nhưng chưa ghi nhận thấy được mối tương quan giữa nồng độ triglyceride máu với nguy cơ xảy ra biến chứng viêm tuy. Liên quan đến dữ liệu kiểu gen của bệnh, mặc dù đột biến trên gen LPL là phổ biến nhất đã được ghi nhận ở các nghiên cứu đã công bố trên các bệnh nhân của các chủng tộc khác nhau, tuy nhiển chúng tôi chỉ gặp 1 bệnh nhân có đột biến của gen này. Trong nghiên cứu này, 4 bệnh nhân có đột biến lặp đoạn c.45_48dup (p.P17AfsX22) trên gen GPIHPB1, tuy biến thể này chưa được báo cáo trên ClinVar and HGMD, nhưng có thể phân loại là biến thế gây bênh vì có gây biến đổi protein do đột biến làm thay đổi khung dịch mã. Trong số 4 bệnh nhân có đột biến chưa được báo cáo này thì có 3 bệnh nhân có kiểu gen đồng hợp tử và 1 bệnh nhân có kiểu gen dị hợp tử kép. Ớ bệnh nhân số 1 dị hợp tử kép còn phát hiện 1 đột biến điểm c.296-1G >A trên gen GPIHPB1, đột biến này cũng chưa từng được báo cáo trước đây, nhưng có thể phân loại là biến thể gây bệnh do được dự đoán gây bất thường gắn nối giữa exon và intron. Kiểu gen của một bệnh nhân có đột biến ở gen LPL ở trạng thái dị hợp tử kép. Đột biến gen này được ghi nhận là nguyên nhân chủ yếu gây tăng triglycerid máu tiên phát nhưng chúng tôi gặp với tỷ lệ nhỏ nhất. Tuy nhiên, cõ̃ mẫu nghiên cứu còn nhỏ và cần tiếp tục phân tích phân tử cho các bệnh nhân có chỉ định để khẳng định phân bố các đột biến của các gen liên quan. Đột biến gen ApoE cũng chỉ gặp ở 1 bệnh nhân và ở dạng di truyền trội [5] [6].

Cả 6 ca bệnh đều đáp ứng tốt với điều chỉnh chế độ ăn: có 3 ca đạt đích điêu trị triglyceride < $5 \mathrm{mmol} / \mathrm{l}$, là đích giúp hạn chế biến chứng tim mạch; cả 6 bệnh đều đạt đích < $10 \mathrm{mmol} / \mathrm{l}$, là đích hạn chế biến chứng viêm tuy. Như vậy, điều chỉnh chế độ ăn và các sản phẩm bổ xung như sử dụng dầu MCT và Omega 3 là các biện pháp an toàn đối với trẻ nhỏ và có hiệu quả trong kiểm soát nồng độ triglycerid máu ở trẻ em.

\section{KẾT LUẬN}

Tăng triglyceride tiên phát có biểu hiện u hạt vàng, gan, lách to hoặc biến chứng viêm tụy cấp, không có bệnh nhân béo phì; nồng độ 
triglyceride ở ngương tăng nặng (> $11 \mathrm{mmol} / \mathrm{l})$. Trong 6 ca bệnh, có 1 ca có đột biến trên gen $\mathrm{LPL}, 4$ ca đột biến mới trên gen GPIHPB1, $1 \mathrm{ca}$ có đột biến trên genApoE. Cả 6 ca bệnh đều đáp ứng với điều chỉnh chế độ ăn. Xác định đôt biến của các gen liên quan có giá trị khẳng định chẩn đoán, phòng bệnh bằng phát hiện dị hợp tử và tư vấn di truyền.

\section{TÀI LIÊU THAM KHẢO}

1. Lewis G.F., Changting X., Robert A.H. (2015). Hypertriglyceridemia in the genomic era: a new paradigm. Endocr Rev, 36(1), 131-47.

2. Davies B.S., Beigneux A.P., Barnes R.H et al. (2010). GPIHBP1 is responsible for the entry of lipoprotein lipase into capillaries. Cell Metab, 12, 42-52.

3. Peterfv M. (2012). Lipase maturation factor 1: a lipase chaperone involved in lipid metabolism. Biochim Biophys Acta, 1821, 790-4.

4. Vrablik M., Hubacek J.A. (2010). Genetic determination of triglyceridemia with special focus on apolipoprotein gene variants. Clinical Lipidology, 5(4), 543-54.

5. Shah A.S., Wilson D.P. (2015). Primary hypertriglyceridemia in children and aldolescents. J Clin lipidol, 9(5), S20-8.

6. Musambil M., Al-Rubeaan K., Al-Qasim S et al. (2020). Primary hypertriglyceridemia: A look back on the clinical classification and genetics of the disease. Curr Diabetes Rev, 16(6), 521-531.

\section{SO SÁNH MộT Số TÁC DỤNG KHÔNG MONG MUỐN CỦA GÂY TÊ Cơ VUÔNG THẮT LƯNG VỚI GÂY TÊ MĂT PHẲNG CƠ NGANG BỤNG DƯớI HƯỚNG DẪN SIÊU ÂM ĐỂ GIẢM ĐAU SAU MỔ CẮT TỬ CUNG HOÀN TOÀN ĐƯờNG BỤNG}

\section{TÓM TẮT}

Mục tiêu: So sánh một số tác dụng không mong muốn của phương pháp gây tê cớ vuông thắt lưng (QL block) với gây tê mặt phẳng cơ ngang bụng (TAP block) dưới hướng dẫn siêu âm để giảm đau sau mổ cắt tử cung hoàn toàn đường bụng. Đối tượng, phương pháp nghiên cứu: 60 bệnh nhân được gâyy tê tuỷ sông để phẫu thuật cắt tử cung hoàn toàn đường bụng, sau mổ được phân bố ngẩu nhiên vào hai nhóm bằng nhau để giảm đau sau mổ bằng $\mathrm{QL}$ block hai bên hoăc TAP block hai bên dưới hướng dẫn của siêu âm, sử dung ropivacain $0,25 \%$ liều $0,3 \mathrm{ml} / \mathrm{kg}$ ở mối bên. Theo dối liên tưc các tác dụng không mong muốn của hai phương pháp này trong 24 giờ đâu sau mổ. Kết quả: Tỷ lê nôn, buồn nôn ở nhóm QL block là 3,33\% so với nhóm TAP block là $6,67 \%$, tỷ lệ ngứa ở hai nhóm là 3,33\%. Không gặp trướng hợp nào bị tụ máu thành bụng, nhiễm khuẩn vị trí gây tê, tổn thương cơ quan trong ổ bụng hay ngộ độc thuốc tê ở cả hai nhóm nghiên cứu. Kết luận: Tác dụng không mong muốn của gây tê cơ vuông thắt lưng tương đương với gây tê mặt phẳng cơ ngang bụng dưới hướng dẫn của siêu ẩm để giảm đau sau mổ cắt tử cung hoàn toàn đường bụng. Không gặp các tai biến nặng nề của cả hai phương pháp này.

\section{${ }^{1}$ Trường Đại học Y Hà Nọi,}

${ }^{2}$ Bệnh viện Sản Nhi Nghệ An

Chiu trách nhiệm chính: Nguyễn Đức Lam

Email: lamgmhs75@gmail.com

Ngày nhận bài: 4.01.2021

Ngày phản biên khoa học: 26.2.2021

Ngày duyệt bài: 9.3.2021

\section{Nguyễn Đức Lam", Trần Thị Phương²}

Tư khoá: Gây tê cơ vuông thắt lưng, gây tê mặt phẳng cơ ngang bụng , cắt tử cung hoàn toàn đường bụng, tác dụng khổng mong muốn.

\section{SUMMARY \\ THE COMPARISON OF THE SIDE EFFECTS \\ OF ULTRASOUND GUIDED QUADRATUS LUMBORUM BLOCK VERSUS TRANSVERSUS ABDOMINIS PLANE BLOCK FOR PAIN RELIEF IN TOTAL ABDOMINAL HYSTERECTOMY}

Objective: To compare the side effects of ultrasound guided Quadratus lumborum (QL) block versus Transversus Abdominis Plane (TAP) block for pain relief of total abdominal hysterectomy. Methods: 60 patients performed spinal anesthesia for total abdominal hysterectomy, were randomly divided into two similar groups to receive analgesia postoperative by ultrasound guided bilateral QL block or bilateral TAP block with ropivacaine $0.25 \%$ dose of $0.3 \mathrm{ml} / \mathrm{kg}$ on each side. We Continuously monitored the side effects of these methods in the first 24 hours after surgery. Results: The rate of nausea and vomiting in the QL block group was 3.33\% compared to $6,67 \%$ in TAP block group the pruritus rate in the two groups was $3.33 \%$. There was no case of abdominal wall hematoma, infection on the needle punture site, intra-abdominal organ damage or local anaesthetic systemic toxicity in both groups. Conclusions: The side effects of ultrasound guided Quadratus lumborum (QL) block was similar to Transversus Abdominis Plane (TAP) block for postoperative pain relief in total abdominal hysterectomy. There was no serious complication in 